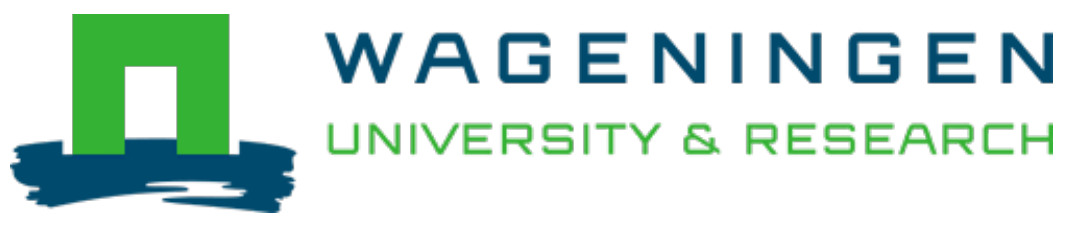

\author{
Protein hydrolysis during soybean tempe fermentation with Rhizopus oligosporus. \\ Journal of Agricultural and Food Chemistry \\ Reu, J.C.; Wolde, R.M.; Groot, J.; Nout, M.J.R.; Rombouts, F.M. et al \\ https://doi.org/10.1021/jf00056a050
}

This publication is made publicly available in the institutional repository of Wageningen University and Research, under the terms of article $25 \mathrm{fa}$ of the Dutch Copyright Act, also known as the Amendment Taverne. This has been done with explicit consent by the author.

Article $25 \mathrm{fa}$ states that the author of a short scientific work funded either wholly or partially by Dutch public funds is entitled to make that work publicly available for no consideration following a reasonable period of time after the work was first published, provided that clear reference is made to the source of the first publication of the work.

This publication is distributed under The Association of Universities in the Netherlands (VSNU) 'Article $25 \mathrm{fa}$ implementation' project. In this project research outputs of researchers employed by Dutch Universities that comply with the legal requirements of Article $25 \mathrm{fa}$ of the Dutch Copyright Act are distributed online and free of cost or other barriers in institutional repositories. Research outputs are distributed six months after their first online publication in the original published version and with proper attribution to the source of the original publication.

You are permitted to download and use the publication for personal purposes. All rights remain with the author(s) and / or copyright owner(s) of this work. Any use of the publication or parts of it other than authorised under article $25 \mathrm{fa}$ of the Dutch Copyright act is prohibited. Wageningen University \& Research and the author(s) of this publication shall not be held responsible or liable for any damages resulting from your (re)use of this publication.

For questions regarding the public availability of this publication please contact openscience.library@wur.nl 


\title{
Protein Hydrolysis during Soybean Tempe Fermentation with Rhizopus oligosporus
}

\author{
Johan C. de Reu,* R. Marcel ten Wolde, Jolan de Groot, M. J. Robert Nout, \\ Frank M. Rombouts, and Harry Gruppen \\ Department of Food Science, Wageningen Agricultural University, Bomenweg 2, \\ 6703 HD Wageningen, The Netherlands
}

\begin{abstract}
Hydrolysis of soybean protein during fermentation in a rotating drum reactor (RDR) was compared with hydrolysis during the traditional stationary tempe fermentation process. An increase of watersoluble nitrogen was observed. After $72 \mathrm{~h}$ of fermentation, 18.5, 25.4, 27.1, and $34.0 \%(\mathrm{w} / \mathrm{w})$ of total $\mathrm{N}$ were found for the traditional stationary process at 25,30 , and $37^{\circ} \mathrm{C}$ and for the RDR at 36 ${ }^{\circ} \mathrm{C}$, respectively, compared to $2.0 \%$ in cooked soybeans at the start of the fermentation. The fungal activity in the RDR continued longer than in the traditional process. This was achieved by avoiding heat and mass transfer limitations. In the RDR a higher degree of hydrolysis, as well as higher levels of water-soluble and TCA-soluble nitrogen, were found after $72 \mathrm{~h}$ of fermentation compared with the stationary process at $37^{\circ} \mathrm{C}$. $\beta$-Conglycinin was hydrolyzed more rapidly than glycinin, which is probably related to the chemical structure; $\beta$-conglycinin is more sensitive toward protease activity.
\end{abstract}

Keywords: Soybeans; proteins; Rhizopus oligosporus; tempe; glycinin; $\beta$-conglycinin

\section{INTRODUCTION}

Tempe is a traditional Indonesian fermented food made from dehulled, soaked, and cooked soybeans inoculated with a mold, usually of the genus Rhizopus. After fermentation has occurred, the soybeans are bound together into a compact cake by dense cottony mycelium. Rhizopus spp. produce a variety of carbohydrases, lipases, proteases, phytases, and other enzymes, which hydrolyze soybean constituents and contribute to the development of the desirable texture, flavor, and aroma of tempe. Enzymatic hydrolysis may also decrease or eliminate antinutritional constituents. Consequently, the nutritional quality of the fermented product may be improved (Nout and Rombouts, 1990; Hachmeister and Fung, 1993).

The effect of fermentation on the total nitrogen content is negligible (Nowak and Szebiotko, 1992), but increases in the concentrations of free amino acids take place. The amino acid pattern, as quantified by the essential amino acid index, is not significantly affected during a $24 \mathrm{~h}$ fermentation. Longer fermentation results in losses of lysine $(25 \%$ lost after $60 \mathrm{~h}$; Winarno and Reddy, 1986; Stillings and Hackler, 1965). Up till now little attention has been paid to the effects of fermentation on the individual subunits of the major soybean proteins.

The major soy proteins are glycinin and $\beta$-conglycinin. Glycinin is composed of six subunits $\left(\mathrm{A}_{n}-\mathrm{B}_{n}\right)$ which are formed of acidic polypeptides $\left(A_{1}-A_{5}\right)$ and basic polypeptides $\left(B_{1}-B_{4}\right)$. These acidic and basic polypeptides are covalently linked to each other by disulfide bonds, to form subunits. Glycinin subunits can be separated into distinct groups: $\mathrm{I}, \mathrm{A}_{1 \mathrm{a}} \mathrm{B}_{2}, \mathrm{~A}_{1 \mathrm{~b}} \mathrm{~B}_{1 \mathrm{~b}}$, and $\mathrm{A}_{2} \mathrm{~B}_{1 \mathrm{a}}$; and II, $\mathrm{A}_{3} \mathrm{~B}_{4}$ and $\mathrm{A}_{5} \mathrm{~A}_{4} \mathrm{~B}_{3}$ (Yamauchi et al., 1991).

$\beta$-Conglycinin, the other major constituent in soybeans, is less well-defined compared with glycinin.

* Author to whom correspondence should be addres. sed (fax +31837084893; e-mail Johan.deReu@zuivel. lmt.wau.nl).
$\beta$-Conglycinin is glycosylated and consists of three subunit combinations of $\alpha(57000-68000 \mathrm{Da}), \alpha^{\prime}$ (57 000-68 000 Da), and $\beta(42000-52000 \mathrm{Da})$, giving seven isomers $\left(B_{0}-B_{6}\right)$ (Yamauchi et al., 1991).

In this study we investigated the influence of incubation temperature and agitation on the proteolysis of soybean proteins during the tempe process. The results obtained with fermentation of Rhizopus oligosporus at 25,30 , and $37{ }^{\circ} \mathrm{C}$ in the traditional stationary process were compared with those obtained in a previously described rotating drum reactor (RDR) (De Reu et al., 1993). Temperature control during solid-substrate fermentation can be achieved in this laboratory system by either discontinuous or continuous rotation and forced evaporation by aeration. As a result of the rotation a more-or-less granular product is obtained, in contrast to the cakelike product resulting from the traditional process.

\section{MATERIALS AND METHODS}

Organism. Rhizopus microsporus var. oligosporus strain LU 575 (NRRL 5905) was grown and maintained at $30^{\circ} \mathrm{C}$ on malt extract agar (Oxoid, CM 59, Basingstoke, Hampshire, England). Sporangiospore suspensions were obtained as previously described by De Reu et al. (1994).

Tempe Manufacturing Process. Dehulled yellow-seeded soybeans (Glycine max) were soaked, cooked, inoculated, and packed in Petri dishes as described previously by De Reu et al. (1994). Petri dishes were incubated at 25,30 , or $37^{\circ} \mathrm{C}$. An autoclaved rotating drum reactor vessel (De Reu et al., 1993) was filled with $1 \mathrm{~kg}$ of cooked and inoculated soybeans. The reactor was placed in a temperature-controlled incubator at $30{ }^{\circ} \mathrm{C}$. During the experiments a discontinuous rotating scheme was used to avoid the substrate temperature's exceeding $36{ }^{\circ} \mathrm{C}$. After the substrate temperature reached $36{ }^{\circ} \mathrm{C}$, the vessel was rotated during $1 \mathrm{~min}$ according to the following sequence: clockwise $(8 \mathrm{~s}, 8 \mathrm{rpm})$, hold ( $2 \mathrm{~s})$, and counterclockwise $(8 \mathrm{~s}, 6 \mathrm{rpm})$. Due to the rotation, the temperature of the substrate dropped $1.5-2.0^{\circ} \mathrm{C}$. After rotation, the reactor vessel was held until the substrate temperature of $36^{\circ} \mathrm{C}$ was reached. Then the rotation cyclus was repeated. This procedure was repeated continuously, resulting in a so-called "sawtooth" temperature pattern (De Reu et al., 1993). 
Samples were taken at various times $(0,14,18,22,26,30$, $38,48,55,66$, and $72 \mathrm{~h}$ ) and immediately frozen with liquid nitrogen. The samples were stored at $-20^{\circ} \mathrm{C}$, lyophilized, and subsequently held at $4{ }^{\circ} \mathrm{C}$ in the dark until analysis. Although incubation would normally be complete after $30-48 \mathrm{~h}$ in a commercial production setting, we continued the fermentation for up to $72 \mathrm{~h}$ to observe the effects of ongoing biochemical processes.

Fractionation of Nitrogen-Containing Compounds. Lyophilized sample ( $7 \mathrm{~g}$ ) was extracted with distilled water $\left(35 \mathrm{~mL}\right.$ ), in a head-over-tail rotator during $30 \mathrm{~min}$ at $4^{\circ} \mathrm{C}$. The suspension was centrifuged $(27000 \mathrm{~g})$ for $10 \mathrm{~min}$ at $4{ }^{\circ} \mathrm{C}$ The supernatant was filtered through a glass filter (Whatman, glass microfiber, catalog no. 1820037 ). The supernatant was designated water-soluble solids (WSS). The residue was washed twice with distilled water $(50 \mathrm{~mL})$, and the resulting filtrates were discarded. The residue remaining on the filter was added to the water-insoluble residue and was lyophilized and weighed; this fraction was designated water-insoluble solids (WIS)

The WSS fraction was boiled for $15 \mathrm{~min}$ to inactivate enzyme activity and was then centrifuged for $10 \mathrm{~min}$ at $27000 \mathrm{~g}$. The pellet, heat-precipitable water-soluble solids (HPWSS), was washed twice with distilled water and freeze-dried. The remaining supernatant was treated with trichloroacetic acid (TCA) to give a final concentration of $13.6 \%(\mathrm{w} / \mathrm{v}) \mathrm{TCA}$ (AdlerNissen, 1986). After one night of storage at $4{ }^{\circ} \mathrm{C}$, the suspension was centrifuged at $4^{\circ} \mathrm{C}$ for $15 \mathrm{~min}$ at $39100 \mathrm{~g}$. The TCA pellet was designated TCA-insoluble solids (TIS) and the supernatant as TCA-soluble solids (TSS). The TIS and TSS fractions were lyophilized and weighed.

All fractions were analyzed for their nitrogen content (w/w of dry matter) using the micro-Kjeldahl technique. The standard deviation of the method was determined by analyzing one sample four times. This resulted in a standard deviation of $\mathrm{N} \pm 0.31 \%$. On the basis of this result and the total data per fermentation condition, it was decided to analyze the other samples only once.

Electrophoresis. SDS-PAGE was performed on the freeze-dried tempe samples using a Protean II electrophoresis system (Bio-Rad, Richmond, CA) essentially according to the procedure of Laemmli (1970). Homogeneous slab gels [concentration monomers $(T)=12.5$ or $15 \%$, cross-linker concentration $(C)=2.2 \%$ ] were used. The gels were stained with Coomassie Brilliant Blue R-250 according to the instructions of the manufacturer.

The optical density of the bands was measured using a laser densitometer (computing densitometer 300A, Molecular Dynamics, Sunnyvale, $\mathrm{CA}$ ) equipped with a helium-neon laser ( $\lambda 672 \mathrm{~nm}$ ) using Imagequant 3.15 software (Molecular Dynamics). Although band patterns for all of the obtained samples were available, we elaborated only on the data of samples after 22 and $66 \mathrm{~h}$ of incubation, as this method is very laborious. The major peaks were identified following the characterization of Wolf et al. (1992); these included peak 1 , $\alpha^{\prime}$ - and $\alpha$-subunits of $\beta$-conglycinin; peak $2, \beta$-subunits of $\beta$-conglycinin; peak $3, \mathrm{~A}_{3}$-glycinin; peak $4, \mathrm{~A}_{1 \mathrm{a}^{-}}, \mathrm{A}_{1 \mathrm{~b}^{-}}$, and $\mathrm{A}_{2^{-}}$ glycinin; and peak 5, B-glycinin.

The peak areas were calculated and expressed as relative intensities. Although equal amounts of protein were used, differences in the absolute recoveries of protein can easily be expected due to possible variation in the (small) amounts of protein brought onto the gels. Therefore, the intensities themselves were not used to compare the various samples.

Degree of Hydrolysis. Twenty-five milliliters of a hot solution $\left(80^{\circ} \mathrm{C}\right)$ of sodium dodecyl sulfate $(10 \mathrm{~g} / \mathrm{L})$ and 1,4 dithiothreitol $(3 \mathrm{~g} / \mathrm{L})$ was added to $\pm 2.0 \mathrm{~g}$ of sample (approximately $1 \mathrm{~g}$ of protein). The mixture was placed in a water bath $\left(100^{\circ} \mathrm{C}\right)$ for $1 \mathrm{~h}$. The solution was then cooled to room temperature, with continuous stirring. The solution was adjusted to $\mathrm{pH} 6$, before excess $(4.5 \mathrm{~mL})$ formaldehyde ( $37 \%$, Merck) was added. Finally, the mixture was titrated with 0.1 $\mathrm{M}$ sodium hydroxide to $\mathrm{pH}$ 9.5. The required volumes for both the fermented sample and the cooked soybeans determined the degree of hydrolysis (Adler-Nissen, 1986).
Table 1. Partition of Nitrogen (\% $w / w$ of Total $N)$ in the Different Fractions of Soybeans

\begin{tabular}{lrrrrr}
\hline & $\begin{array}{c}\text { WIS }^{a} \\
(\%)\end{array}$ & $\begin{array}{c}\text { WSS }^{a} \\
(\%)\end{array}$ & $\begin{array}{c}\mathrm{HPWSS}^{a} \\
(\%)\end{array}$ & $\begin{array}{c}\mathrm{TIS}^{a} \\
(\%)\end{array}$ & $\begin{array}{c}\mathrm{TSS}^{a} \\
(\%)\end{array}$ \\
\hline raw beans & 54.3 & 45.7 & 29.6 & 12.36 & 2.9 \\
soaked beans & 92.6 & 7.4 & 1.0 & 6.10 & 6.1 \\
cooked beans & 113.6 & 2.0 & 0.0 & 2.54 & 2.5
\end{tabular}

${ }^{a}$ WIS, water-insoluble solids; WSS, water-soluble solids; HPWSS, heat-precipitable water-soluble solids; TIS, TCA-insoluble solids; TSS, TCA-soluble solids.

Table 2. Total Nitrogen and pH during the Fermentation of Soybeans with $R$. oligosporus at 25,30 , and $37^{\circ} \mathrm{C}$ in Petri Dishes and at $36^{\circ} \mathrm{C}$ in the RDR after $65 \mathrm{~h}$

\begin{tabular}{lcc}
\hline \multicolumn{1}{c}{ sample } & $\begin{array}{c}\text { total }(\mathrm{N} \times 6.25) \text { content } \\
(\% \text { w/w of dry matter })\end{array}$ & $\mathrm{pH}$ \\
\hline raw beans & 44.1 & 6.7 \\
soaked beans & 46.1 & 4.4 \\
cooked beans & 45.0 & 4.5 \\
RDR, 65 h & 49.5 & 5.9 \\
$25^{\circ} \mathrm{C}, 65 \mathrm{~h}$ & 51.7 & 5.8 \\
$30^{\circ} \mathrm{C}, 65 \mathrm{~h}$ & 52.4 & 5.8 \\
$37^{\circ} \mathrm{C}, 65 \mathrm{~h}$ & 53.8 & 6.1
\end{tabular}

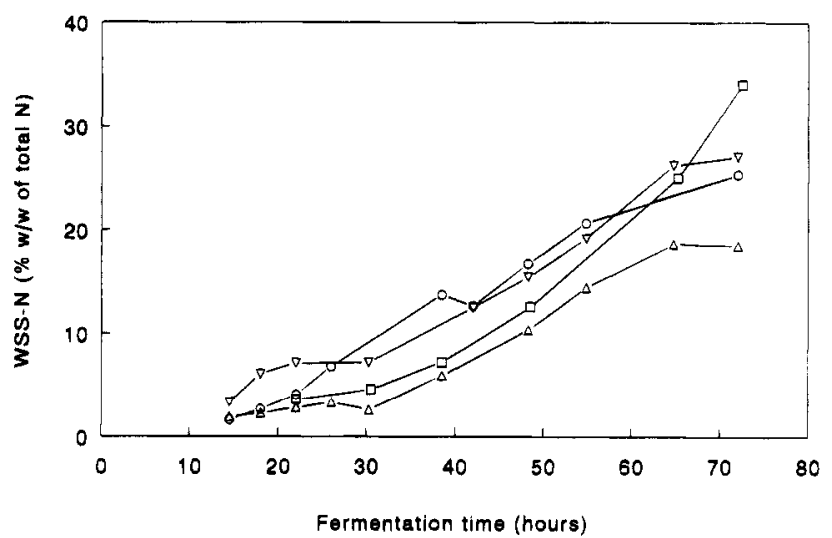

Figure 1. Water-soluble nitrogen (WSS-N) content in the fermentation of soybeans with $R$. oligosporus during the traditional process at $25(\Delta), 30(0)$, and $37^{\circ} \mathrm{C}(\nabla)$ and with the $\mathrm{RDR}$ at $36^{\circ} \mathrm{C}(\square)$.

\section{RESULTS}

Initially $45.7 \%(\mathrm{w} / \mathrm{w}$ of total $\mathrm{N}$ ) of the nitrogen was water-soluble in the raw beans as shown in Table 1 . During soaking and acidification the water-soluble nitrogen proportion decreased to $7.4 \%$ (w/w of total $\mathrm{N}$ ). Cooking decreased the water-soluble nitrogen proportion further to $2.0 \%(\mathrm{w} / \mathrm{w}$ of total $\mathrm{N})$.

During fermentation we observed increases in protein content (based on solids content) and $\mathrm{pH}$ of the freezedried material as shown in Table 2. During soaking the $\mathrm{pH}$ of the beans decreased from 6.7 to 4.4. Cooking resulted in a slight increase to 4.5 , while during fermentation the $\mathrm{pH}$ increased to approximately 6.0.

The proportion of the water-soluble nitrogen (WSSN) for the different fermentations is shown in Figure 1. The WSS-N proportion increased during fermentation initially in this order: $37^{\circ} \mathrm{C}, 30^{\circ} \mathrm{C}, \mathrm{RDR}$, and $25^{\circ} \mathrm{C}$. At $25^{\circ} \mathrm{C}$ the increase in the proportion of WSS-N started slowly but still reached $18.7 \%$ (w/w of total N) after 72 $\mathrm{h}$. Incubation at 30 and $37^{\circ} \mathrm{C}$ increased the proportion of WSS-N to 25.4 and $27.1 \%$ (w/w of total N), respectively. In the RDR the proportion of WSS-N increased at the same rate as the traditional process at $25{ }^{\circ} \mathrm{C}$ up to $48 \mathrm{~h}$. However, during the third day of the process the increase was more pronounced compared to any of the nonagitated fermentations and resulted in a final 


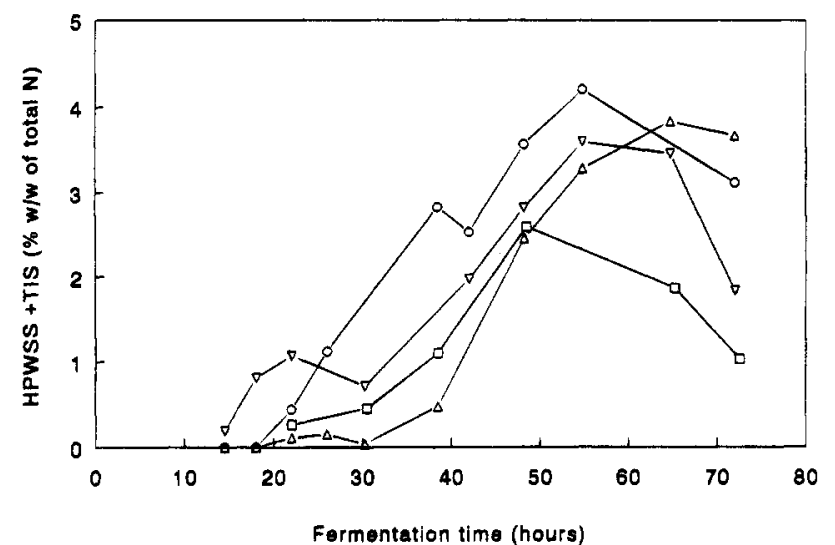

Figure 2. Sum of the residue after boiling the water-soluble fraction (HPWSS) and the TCA-insoluble fraction (TIS) in the fermentation of soybeans with $R$. oligosporus during the traditional process at $25(\Delta), 30(0)$, and $37^{\circ} \mathrm{C}(\nabla)$ and with the rotating drum reactor at $36^{\circ} \mathrm{C}(\square)$.

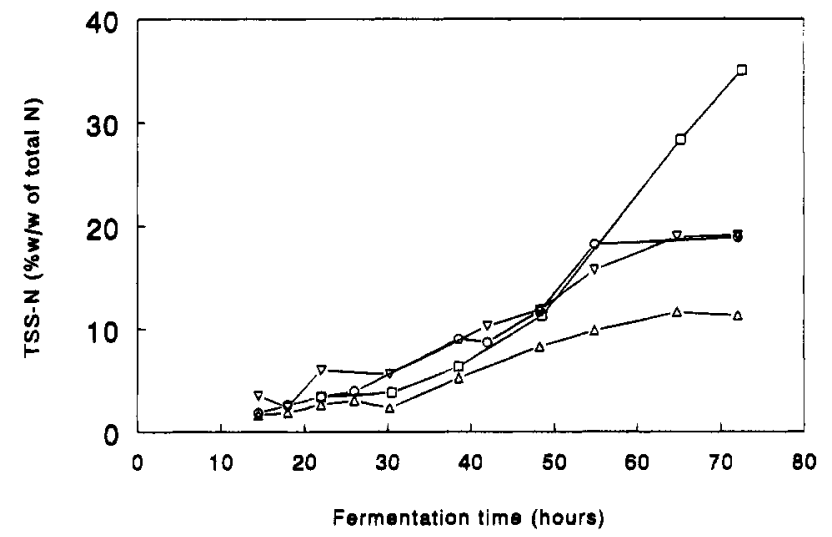

Figure 3. TCA-soluble nitrogen (TSS) content in the fermentation of soybeans with $R$. oligosporus during the traditional process at $25(\Delta), 30(0)$, and $37^{\circ} \mathrm{C}(\nabla)$ and with the RDR at $36{ }^{\circ} \mathrm{C}(\square)$.

WSS-N proportion of $34.0 \%$ (w/w of total N) after $72 \mathrm{~h}$ of fermentation. As expected, the WIS nitrogen proportion showed an inverse pattern to the increasing proportion of WSS-N (data not shown). The nitrogen proportions of the two fractions should add up to give $100 \%$. In this study (40 samples), an average value of $95.1 \pm 4.6 \%$ was obtained.

The sums of nitrogen present in the fractions HPWSS and TIS expressed as the proportion of total N are shown in Figure 2. They formed a minority of the WSS fraction, as a maximum of $4 \%(\mathrm{w} / \mathrm{w}$ of total $\mathrm{N})$ was found in those fractions. The maxima indicate that after 50$60 \mathrm{~h}$ of fermentation, the fractions were hydrolyzed further to smaller peptides or amino acids which were soluble in $13.6 \%$ TCA. For the RDR the maximum is reached after $48 \mathrm{~h}$ and for the traditional process at 25 , 30 , and $37{ }^{\circ} \mathrm{C}$ after 65,55 , and $55 \mathrm{~h}$, respectively.

The proportions of TCA-soluble nitrogen (TSS-N) for the different fermentations are shown in Figure 3. The level of TSS-N increased less at $25^{\circ} \mathrm{C}$ than at higher temperatures. The differences between 30 and $37^{\circ} \mathrm{C}$ were small, while after $50 \mathrm{~h}$, the level in the RDR increased rapidly to $34 \%$ ( $\mathrm{w} / \mathrm{w}$ of total $\mathrm{N}$ ).

The degree of hydrolysis (DH) of the different fermented samples is shown in Figure 4. The hydrolysis at $25^{\circ} \mathrm{C}$ started later and increased less than at 30 and $37^{\circ} \mathrm{C}$. Until $48 \mathrm{~h}$ the differences between 30 and $37^{\circ} \mathrm{C}$ and the RDR were small, but beyond $48 \mathrm{~h}$ the $\mathrm{DH}$ increased rapidly to a level of $46 \%$ in the RDR.

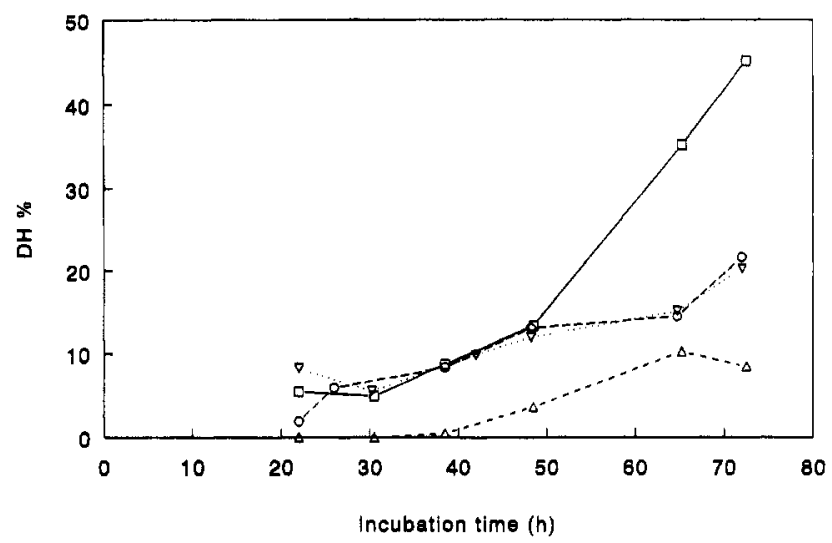

Figure 4. Degree of hydrolysis (DH) in the fermentation of soybeans with $R$. oligosporus during the traditional process at $25(\Delta), 30(O)$, and $37^{\circ} \mathrm{C}(\nabla)$ and with the RDR at $36^{\circ} \mathrm{C}$ (口).

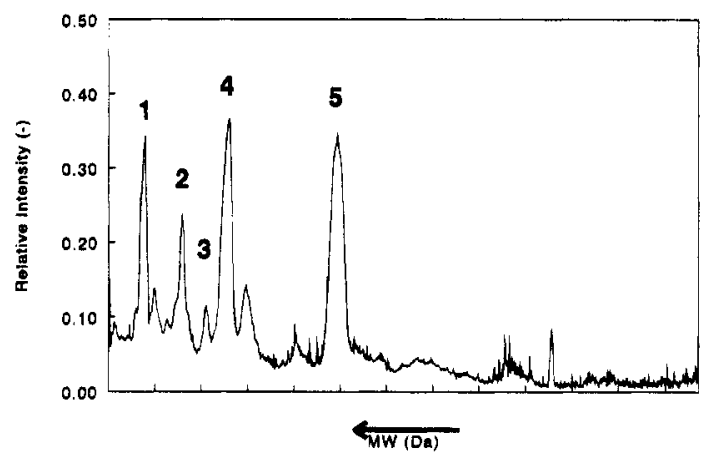

Figure 5. Intensities of bands on a representative SDSPAGE gel of freeze-dried tempe obtained after $22 \mathrm{~h}$ of fermentation at $25^{\circ} \mathrm{C}$. Peak $1, \alpha^{\prime}$ - and $\alpha$-subunits of $\beta$-conglycinin; peak $2, \beta$-subunits of $\beta$-conglycinin; peak $3, \mathrm{~A}_{3^{-}}$ glycinin; peak 4, $\mathrm{A}_{1 \mathrm{a}^{-}}, \mathrm{A}_{1 b^{-}}$, and $\mathrm{A}_{2}$-glycinin; peak 5, B-glycinin.

Table 3. Ratios of $\beta$-Conglycinin:Glycinin, $\alpha$ - and $\alpha^{\prime}$-Subunits of $\beta$-Conglycinin: $\beta$-Subunits of $\beta$-Conglycinin, and A-Glycinin:B-Glycinin in Soybeans during the Traditional Stationary Process at 25,30 , and $37^{\circ} \mathrm{C}$ during the Agitated Process in the RDR at $36^{\circ} \mathrm{C}$

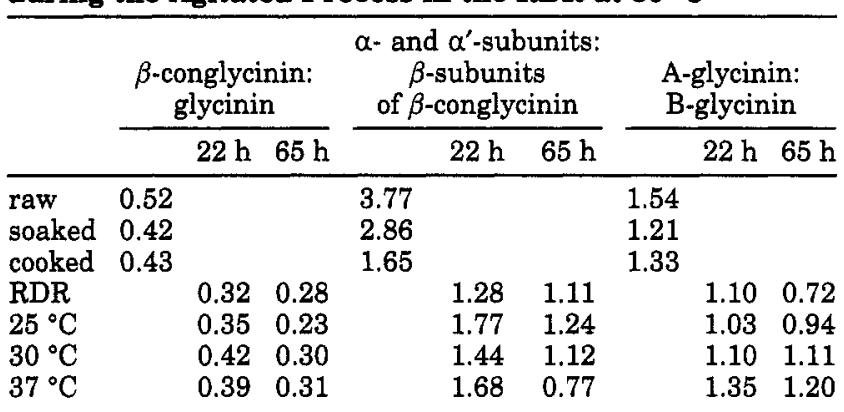

The freeze-dried samples were analyzed by SDSPAGE to characterize the hydrolysis pattern in tempe. A typical pattern is shown in Figure 5 after $22 \mathrm{~h}$ of fermentation at $25^{\circ} \mathrm{C}$. This pattern was determined by measuring the intensities of the different bands on the gel.

In Table 3 the changes in the ratio between $\beta$-conglycinin (peaks 1 and 2 ) and glycinin (peaks $3+4+5$ ) as well as the ratio of $\alpha$ - and $\alpha^{\prime}$-subunits of $\beta$-conglycinin (peak 1) to $\beta$-subunits of $\beta$-conglycinin (peak 2) and the ratio of A-polypeptides of glycinin (peaks $3+4$ ) to B-polypeptides of glycinin (peak 5) are shown during the process. During preprocessing and fermentation conglycinin appears to be hydrolyzed to a higher extent than glycinin, as the ratio decreased from 0.52 in the raw beans to a minimum of 0.23 after $65 \mathrm{~h}$ of fermenta- 
tion at $25^{\circ} \mathrm{C}$. The $\alpha$ - and $\alpha^{\prime}$-subunits of $\beta$-conglycinin are hydrolyzed to a larger extent than the $\beta$-subunits of $\beta$-conglycinin, while the ratio of A-polypeptides of glycinin to B-polypeptides of glycinin decreased more rapidly in the $R D R$ than in the nonagitated fermentations.

\section{DISCUSSION}

During fermentation a slight apparent increase in total protein content was observed. Several investigators reported on the total protein content during tempe fermentation. Van Buren et al. (1972) observed a slight decrease in total protein from 43.2 to $41.6 \%$ (w/w of dry matter). Slight increases were observed by Nowak and Szebiotko (1992) from 45.1 to $48.8 \%$ (w/w of dry matter), by Van der Riet et al. (1987) from 40.1 to 49.3 (w/w of dry matter), and by Murata et al. (1967) from 45.7 to $50.6 \%$ (w/w of dry matter). In addition, Baumann et al. (1990) concluded that there were no differences in nitrogen content during fermentation. The most likely explanation of an apparent increase in total protein content is that there is a shift in the composition of the dry matter during fermentation. There is a loss of $10 \%$ dry matter during fermentation (Van der Riet et al., 1987). During fermentation carbohydrates and lipids (De Reu et al., 1994) were used to form biomass, carbon dioxide, and water. This would result in a relative increase in protein content. Increases in total protein content are small but seem to be related to the growth rate of $R$. oligosporus. The optimum temperature for growth is about $37-42{ }^{\circ} \mathrm{C}$; the lower the incubation temperature, the smaller the observed increases in total protein content.

The decrease in the water-soluble nitrogen during soaking was probably due to leaching into the soak water and more importantly to the drop in $\mathrm{pH}$ to 4.2 in the soak water. Lah and Cheryan (1980) showed that $\mathrm{pH}$ has a strong effect on the water solubility of soybean proteins. During cooking the remaining water-soluble protein became insoluble due to denaturation. In the traditional process the fractions TSS-N in WSS-N were $0.61,0.74$, and 0.70 after $72 \mathrm{~h}$ of incubation at 25,30 , and $37^{\circ} \mathrm{C}$, respectively, while in the RDR all WSS-N had turned into TSS-N after the same incubation time. On the basis of the higher values for the DH and the fact that almost all of the WSS-N was soluble in TCA, it can be concluded that in the RDR an exoprotease was active and that the product was hydrolyzed to smaller fractions (e.g. amino acids).

In the literature little attention has been paid to protease production by $R$. oligosporus. Wang et al. (1974) characterized the extracellular proteases as aspartic proteases, having endopeptidase activities. In the RDR the gradients of oxygen, carbon dioxide, and temperature are less than in the traditional system. Therefore, the activity of exoproteases might be related to the greater availability of oxygen, which enhances growth, and hence greater production of protease or to shear forces during rotation or to temperature.

Protease activity in $R$. oligosporus was measured intracellularly ( 2 units $/ \mathrm{mg}$ of protein after $48 \mathrm{~h}$ of incubation), extracellularly ( $4.1 \mathrm{units} / \mathrm{mg}$ after $48 \mathrm{~h}$ of incubation), and in the debris ( $2 \mathrm{units} / \mathrm{mg}$ of protein) by Baumann (1992). It was not determined whether the proteases had exo or endo activity. Due to disruption of the hyphae, both the extracellular and intracellular enzyme activities as well as some of the activity in the debris might be pooled, and the resulting in- creased level of extracellular activity might be an explanation for the increased degree of hydrolysis in the RDR.

In previous studies we have shown that it was possible to control the temperature during the fermentation of soybeans to tempe (De Reu et al., 1993). In this study it is shown that there are no significant differences of proteolysis between the traditional stationary process and the rotating drum reactor during the first $48 \mathrm{~h}$ of fermentations. However, the fungal activity lasted longer in the RDR than in the traditional process, as shown by the higher degree of hydrolysis, the higher content of WSS-N, and the differences in TSS nitrogen. Figure 3 shows that during nonagitated fermentations (at 25,30 , and $37^{\circ} \mathrm{C}$ ) the TSS-N leveled off after $48 \mathrm{~h}$ while the level still increased in the RDR. This might be due to the limited heat and mass transfer in the nonagitated systems.

It is shown by De Reu et al. (1995) that the lagphase is reduced at higher incubation temperatures. Therefore, we were not suprised that in Figure 4 the rate of hydrolysis in the stationary process at $37^{\circ} \mathrm{C}$ is higher than at 30 and at $25^{\circ} \mathrm{C}$.

During fermentation we observed a shift in the ratio of $\beta$-conglycinin to glycinin from 0.52 of raw beans to a minimum of 0.23 after $65 \mathrm{~h}$ of fermentation at $25^{\circ} \mathrm{C}$. This implies that $\beta$-conglycinin was decomposed more rapidly than glycinin. This phenomenon was reported earlier by $\mathrm{Kim}$ et al. (1990) for different microbial enzymes and also by Romagnola et al. (1990) in the rumen of Holstein cows. The resistance to degradation of glycinin compared to $\beta$-conglycinin is probably associated with its chemical and physical structure.

The shift in the ratio of $\alpha$ - and $\alpha^{\prime}$-subunits of $\beta$-conglycinin to $\beta$-subunits of $\beta$-conglycinin from 3.77 in the raw beans to 0.77 in the fermented product after $65 \mathrm{~h}$ of incubation at $37^{\circ} \mathrm{C}$ implies that the $\alpha^{\prime}$ - and $\alpha$-subunits are more rapidly degraded during fermentation. Qi et al. (1992) observed similar patterns due to endogenous soybean protease activity (protease $C_{1}$ ) during seed imbibition. It is expected that during the soaking of the soybeans endogenous enzymes could be active; however, they will be inactivated during cooking. During the fungal fermentation stage the degradation of the $\alpha$ - and $\alpha^{\prime}$-subunits of $\beta$-conglycinin is prolonged. This is probably caused by fungal proteases instead of endogenous protease activity.

The shift in the ratio of A-polypeptides of glycinin to B-polypeptides of glycinin from 1.54 in the raw beans to 0.72 in the RDR after $65 \mathrm{~h}$ of incubation implies that the A-polypeptides are decomposed more rapidly than the B-polypeptides of glycinin; Romagnolo et al. (1990) observed a similar pattern for proteolysis in the rumen of Holstein cows.

As tempe manufacture fermentation is usually stopped after $30-48 \mathrm{~h}$, the differences in protein hydrolysis of the traditional product and the RDR product are small. Protein hydrolysis as an important factor affecting the taste of the final product is the subject of further study.

\section{LITERATURE CITED}

Adler-Nissen, J. Enzymic Hydrolysis of Food Proteins; Elsevier Applied Science Publishers: London, 1986.

Baumann, U. Ph.D. Dissertation, Westfälische Wilhelms Universität Münster, Germany, 1992.

Baumann, U.; Bisping, B.; Rehm H. J. Content and release of amino acids during the fermentation of tempe by several strains of Rhizopus species. In DECHEMA Biotechnol. Conf. 1990, 4, Part A, 205-208. 
De Reu, J. C.; Zwietering, M. H.; Rombouts, F. M.; Nout, M. J. R. Temperature control in solid-substrate fermentation through discontinuous rotation. Appl. Microbiol. Biotechnol. 1993, 40, 261-265.

De Reu, J. C.; Ramdaras, D.; Rombouts, F. M.; Nout, M. J. R. Changes in soya bean lipids during tempe fermentation. Food Chem. 1994, 50, 171-175.

De Reu, J. C.; Rombouts, F. M; Nout, M. J. R. Influence of acidity and initial substrate temperature on germination of Rhizopus oligosporus sporangiospores in tempe fermentation. J. Appl. Bacteriol. 1995, 75, 200-208.

Hachmeister, K. A.; Fung, D. Y. C. Tempeh: a mold-modified indigenous fermented food made from soybeans and or cereal grains. Crit. Rev. Microbiol. 1993, 19, 137-188.

Kim, S. Y.; Park, P. S-W.; Rhee, K. C. Functional properties of proteolytic enzyme modified soy protein isolate. J. Agric. Food Chem. 1990, 38, 651-656.

Laemmli, U. K. Cleavage of structural proteins during assembly of the head of bacteriophage T4. Nature 1970, 227, 680-685.

Lah, C. L.; Cheryan, M. Protein solubility characteristics of an ultra-filtered full-fat soybeans product. J. Agric. Food Chem. 1980, 28, 911-916.

Murata, K.; Ikehata, H.; Miyamoto, T. Studies on the nutritional value of tempeh. J. Food Sci. 1967, 32, 580-586.

Nout, M. J. R.; Rombouts, F. M. Recent developments in tempe research. J. Appl. Bacteriol. 1990, 69, 609-633.

Nout, M. J. R.; De Dreu, M. A.; Zuurbier, A. M.; Bonants-Van Laarhoven, T. M. G. Ecology of controlled soya bean acidification for tempe manufacture. Food Microbiol. 1987, 4, 165-172.

Nowak, J.; Szebiotko, K. Some biochemical changes during soybean and pea tempeh fermentation. Food Microbiol. 1992, 9, 37-43.

Qi, X.; Wilson, K. A.; Tan-Wilson, A. L. Characterization of the major protease involved in the soybean $\beta$-conglycinin storage protein mobilization. Plant Physiol. 1992, 99, 725733.
Romagnolo, D.; Polan, C. E.; Barbeau, W. E. Degradability of soybean meal protein fractions as determined by sodium dodecyl sulfate-polyacrylamide gel electrophoresis. J. Dairy Sci. 1990, 73, 2379-2385.

Stillings, B. R.; Hackler, L. R. Amino acid studies on the effect of fermentation time and heat processing of tempeh. J. Food Sci. 1965, 30, 1043.

Van Buren, J. P.; Hackler, L. R.; Steinkraus, K. H. Solubilization of soybean tempe constituents during fermentation. Cereal Chem. 1972, 49, 208-210.

Van der Riet, W. B.; Wight, A. W.; Cilliers, J. J. L.; Datel, J. M. Food chemical analysis of tempeh prepared from south african-grown soybeans. Food Chem. 1987, 25, 197-206.

Wang, H. L.; Vespa, J. B.; Hesseltine, C. W. Acid protease production by fungi used in soybean food fermentation. Appl. Microbiol. 1974, 27, 906-911.

Winarno, F. G.; Reddy, N. R. Tempe. In Legume Based Fermented Foods; Reddy, N. R., Pierson, M. D., Salunkhe, D. K., Eds.; CRC Press: Boca Raton, FL, 1986; pp 95-117.

Wolf, W. J.; Petterson, R. E.; Schaer, M. L. Preparative reversed-phase high performance chromatography of soybean proteins and characterization of fractions by gel electrophoresis. J. Agric. Food Chem. 1992, 40, 1809-1816.

Yamauchi, F.; Yamagishi, T.; Iwabuchi, S. Molecular understanding of heat-induced phenomena of soybean protein. Food Rev. Int. 1991, 7, 283-322.

Received for review December 15, 1994. Revised manuscript received May 22, 1995. Accepted May $31,1995{ }^{\otimes}$ We gratefully acknowledge the financial support of Nutricia Research, Zoetermeer, The Netherlands.

JF940711E

${ }^{\otimes}$ Abstract published in Advance ACS Abstracts, July $1,1995$. 